\title{
Protective effects of transduced Tat-DJ-1 protein against oxidative stress and ischemic brain injury
}

\author{
Hoon Jae Jeong ${ }^{1 *}$, Dae Won Kim ${ }^{1 *}$, Mi Jin Kim , \\ Su Jung Woo', Hye Ri Kim", So Mi Kim", \\ Hyo Sang Jo ${ }^{1}$, Hyun Sook Hwang ${ }^{1}$, \\ Duk-Soo Kim ${ }^{2}$, Sung-Woo $\mathrm{Cho}^{3}$, Moo Ho Won ${ }^{4}$, \\ Kyu Hyung Han', Jinseu Park', \\ Won Sik Eum ${ }^{1,5}$ and Soo Young Choi ${ }^{1,5}$ \\ ${ }^{1}$ Department of Biomedical Science \\ Research Institute of Bioscience and Biotechnology \\ Hallym University \\ Chunchon 200-702, Korea \\ ${ }^{2}$ Department of Anatomy \\ College of Medicine \\ Soonchunhyang University \\ Cheonan 330-090, Korea \\ ${ }^{3}$ Department of Biochemistry and Molecular Biology \\ University of Ulsan College of Medicine \\ Seoul 138-736, Korea \\ ${ }^{4}$ Department of Neurobiology \\ School of Medicine \\ Kangwon National University \\ Chuncheon 200-701, Korea \\ ${ }^{5}$ Corresponding authors: Tel, 82-33-248-2112; \\ Fax, 82-33-241-1463; E-mail, sychoi@ hallym.ac.kr (S.Y.C.) \\ Tel, 82-33-248-2112; Fax, 82-33-241-1463; \\ E-mail, wseum @ hallym.ac.kr (W.S.E.) \\ *These authors contributed equally to this work. \\ http://dx.doi.org/10.3858/emm.2012.44.10.067
}

Accepted 30 July 2012

Available Online 31 July 2012

Abbreviations: DCF-DA, 2',7'-dichlorofluorescein diacetate; MDA, malondialdehyde; PTD, protein transduction domain; ROS, reactive oxygen species

\begin{abstract}
Reactive oxygen species (ROS) contribute to the development of a number of neuronal diseases including ischemia. DJ-1, also known to PARK7, plays an important role in transcriptional regulation, acting as molecular chaperone and antioxidant. In the present study, we investigated whether DJ-1 protein shows a
\end{abstract}

\begin{abstract}
protective effect against oxidative stress-induced neuronal cell death in vitro and in ischemic animal models in vivo. To explore $\mathrm{DJ}-1$ protein's potential role in protecting against ischemic cell death, we constructed cell permeable Tat-DJ-1 fusion proteins. Tat-DJ-1 protein efficiently transduced into neuronal cells in a doseand time-dependent manner. Transduced Tat-DJ-1 protein increased cell survival against hydrogen peroxide $\left(\mathrm{H}_{2} \mathrm{O}_{2}\right)$ toxicity and also reduced intracellular ROS. In addition, Tat-DJ-1 protein inhibited DNA fragmentation induced by $\mathrm{H}_{2} \mathrm{O}_{2}$. Furthermore, in animal models, immunohistochemical analysis revealed that Tat-DJ-1 protein prevented neuronal cell death induced by transient forebrain ischemia in the CA1 region of the hippocampus. These results demonstrate that transduced Tat-DJ-1 protein protects against cell death in vitro and in vivo, suggesting that the transduction of Tat-DJ-1 may be useful as a therapeutic agent for ischemic injuries related to oxidative stress.
\end{abstract}

Keywords: brain ischemia; CA1 region, hippocampal; cell survival; neurons; PARK7 protein, human; reactive oxygen species; toxicity

\section{Introduction}

Cerebral ischemia is caused by the interruption of the brain blood supply leading to neuronal dysfunctions and cell death. Reactive oxygen species (ROS) are natural and inevitable by-products of various cellular processes involving interactions with oxygen. ROS interact with cellular components and damage macromolecules such as proteins, lipids, as well as the DNA in cells by altering their structures and functions, prolonged exposure to which contributes significantly to the pathological processes of a number of human diseases and cell death (Hata et al., 2000; Alexandrova et al., 2004; Andersen, 2004; Schaller and Graf, 2004; Margaill et al., 2005). Enormous increases of ROS are well known to be associated with neuronal cell death during ischemia/reperfusion (Andersen, 2004; Margaill et al., 2005). Therefore, the regulation of ROS production plays an important role in protecting the 
brain against ischemic injury.

DJ-1 protein also called PARK7, was originally identified as an oncogene and is well known as an autosomal recessive gene of Parkinson's disease. $\mathrm{DJ}-1$ is a homodimeric protein belonging to the Thi/Pfp1 superfamily, highly conserved in most living things from human beings to Escherichia coli and is localized in the cytoplasm, nucleus, and mitochondria (Nagakubo et al., 1997; Bonifati et al., 2003; Lee et al., 2003; Wilson et al., 2004; Gupta et al., 2008). DJ-1 protein has multiple functions including antioxidant activity, chaperone-like properties, and transcriptional regulation (Menzies et al., 2005; Xu et al., 2005; Zhou et al., 2006). The protective role of DJ-1 against oxidative stress is well known in PD, however, the roles played by DJ-1 against ischemia are unclear.

Protein transduction technology has been developed for therapeutic purposes to deliver a range proteins into cells and tissues. Protein transduction domains (PTDs), also known as cell penetrating peptides (CPPs), have been shown to deliver proteins across cell membranes and have numerous applications in protein therapy. Tat peptide, a basic domain of the HIV-1 Tat protein, is well known among the various PTDs (Wadia and Dowdy, 2002, 2003). Although PTD fusion proteins have been used to deliver therapeutic proteins in vitro and in vivo, the exact mechanism remains unclear. In previous studies we have shown in vitro and in vivo that that various transduced fusion proteins efficiently protected against cell death (Kwon et al., 2000; Eum et al., 2004; Choi et al., 2006; An et al., 2008; Kim et al., 2010).

In this study, we prepared Tat-DJ-1 proteins to examine the protective effects of DJ-1 on ischemic damage. Our results indicate that Tat-DJ-1 protein efficiently transduced into cells and protected against cell death in vitro and in vivo leading us to suggest that Tat-DJ-1 protein may be a potential therapeutic agent for transient forebrain ischemia and various neuronal diseases related to oxidative stress, including PD.

\section{Results}

\section{Expression and purification of Tat-DJ-1 protein}

We constructed a cell permeable Tat-DJ-1 expression vector ( $p$ Tat-DJ-1), which contained a consecutive cDNA sequence encoding the human DJ-1, a Tat protein transduction domain (Tat49-57), and six histidine residues at the amino-termius. Also, we constructed a DJ-1 expression vector to produce control DJ-1 protein without an HIV-1 Tat protein transduction domain (Figure 1A).
A

$$
\begin{array}{ll}
\text { Tat-DJ-1 His-Tag - Tat }- \text { DJ-1 } \\
\end{array}
$$

Control DJ-1 His-Tag - DJ-1
B

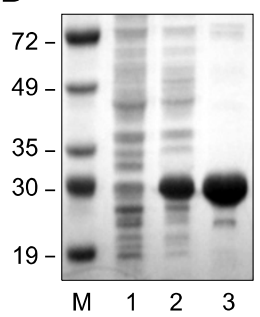

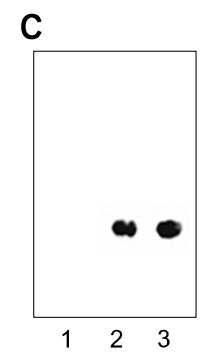

Figure 1. Purification of Tat-DJ-1 protein. A schematic representation of the Tat-DJ-1 protein (A). Expressed and purified fusion proteins were analyzed by $12 \%$ SDS-PAGE (B) and subjected to Western blot analysis with an anti-rabbit polyhistidine antibody (C). Lanes in $B$ and $C$ are as follows: lane 1, non-induced Tat-DJ-1; lane 2, induced Tat-DJ-1; lane 3, purified Tat-DJ-1.

After the induction of expression, Tat-DJ-1 proteins were purified using a $\mathrm{Ni}^{2+}$-nitrilotriacetic acid Sepharose affinity column and PD-10 column chromatography. SDS-PAGE and Western blot analysis of the purified Tat-DJ-1 proteins were performed. As shown in Figure 1B, Tat-DJ-1 proteins were expressed and the purified recombinant Tat-DJ-1 proteins had estimated molecular masses of approximately $28 \mathrm{kDa}$. Tat-DJ-1 proteins were confirmed by Western blot analysis using an anti-rabbit polyhistidine antibody (Figure 1C).

\section{Transduction of Tat-DJ-1 protein into neuronal cells}

We analyzed the transduction of Tat-DJ-1 proteins by adding them to an astrocyte culture medium at a concentration of $3 \mu \mathrm{M}$ for various periods of time $(10-60 \mathrm{~min})$, and then analyzed the transduced protein levels by Western blotting. The intracellular concentration of transduced Tat-DJ-1 proteins in cells was detected within $10 \mathrm{~min}$ and gradually increased until $60 \mathrm{~min}$. The dose-dependency of the transduction of Tat-DJ-1 proteins was further analyzed. Various concentrations $(0.5-3 \mu \mathrm{M})$ of Tat-DJ-1 proteins were added to astrocytes in culture for $60 \mathrm{~min}$, and the levels of transduced proteins were measured by Western blotting. The fusion proteins transduced into astrocytes in a concentration dependent manner. As shown in Figures $2 \mathrm{~A}$ and 2B, Tat-DJ-1 protein efficiently transduced into astrocytes in a time- and dose-dependent manner. However, the control DJ-1 did not transduce into the cells. The intracellular stability of transduced Tat-DJ-1 proteins in astrocytes 
A

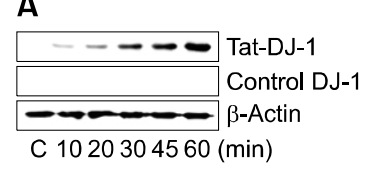

B
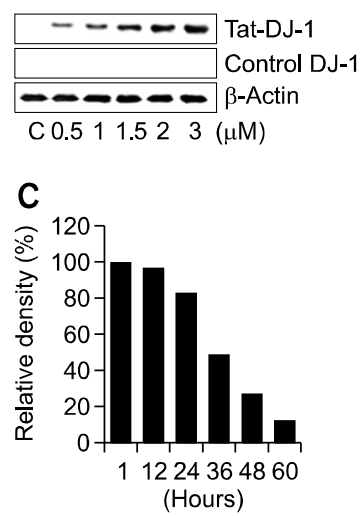

Figure 2. Transduction of Tat-DJ-1 proteins into neuronal cells. Tat-DJ-1 $(3 \mu \mathrm{M})$ and control DJ-1 were added to the astrocytes culture media for 10-60 min (A), Tat-DJ-1 (0.5-3 $\mu \mathrm{M})$ and control DJ-1 were added to the astrocytes culture media for $60 \mathrm{~min}(\mathrm{~B})$, astrocytes pretreated with $3 \mu \mathrm{M}$ Tat-DJ-1 were incubated for 1-72 $\mathrm{h}$, and analyzed by Western blotting and bands intensity by densitometer (C). The distribution of transduced into astrocytes (D) and HT-22 cells (E) with Tat-DJ-1 was observed by fluorescence microscopy. Scale bar $=20 \mu \mathrm{m}$ and $50 \mu \mathrm{m}$, respectively.

is shown in Figure 2C. Transduced protein levels were analyzed by Western blotting and bands intensity by densitometer. The intracellular level of transduced Tat-DJ-1 in cells was initially detected after $1 \mathrm{~h}$. Though the level declined gradually over the period of observation significant levels of transduced Tat-DJ-1 protein persisted in the cells for $60 \mathrm{~h}$. Also, we determined the transduction of Tat-DJ-1 protein into hippocampal neuronal cells, HT-22. Tat-DJ-1 protein transduction into HT-22 cells was similar to that of astrocytes. These results indicate that Tat-DJ-1 protein can not only be transduced into astrocytes but also HT-22 cells (data not shown).

To further clarify the cellular localization of transduced proteins into astrocytes and HT-22 cells, transduced cells were double stained with the nucleus specific marker DAPI. As shown in Figures $2 \mathrm{D}$ and $2 \mathrm{E}$, Tat-DJ-1 protein was detected in the cytoplasm and in the nucleus of transduced cells. These results indicate that Tat-DJ-1 protein efficiently transduced into neuronal cells.

\section{Transduced Tat-DJ-1 proteins affect the viability of cells under oxidative stress}

To determine whether transduced Tat-DJ-1 protein protects cells against oxidative stress, cell viability

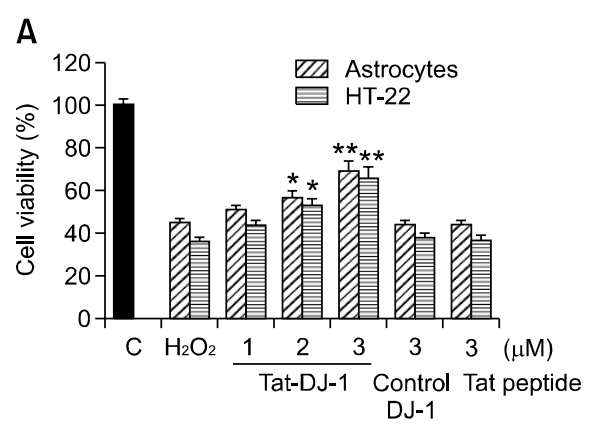

B

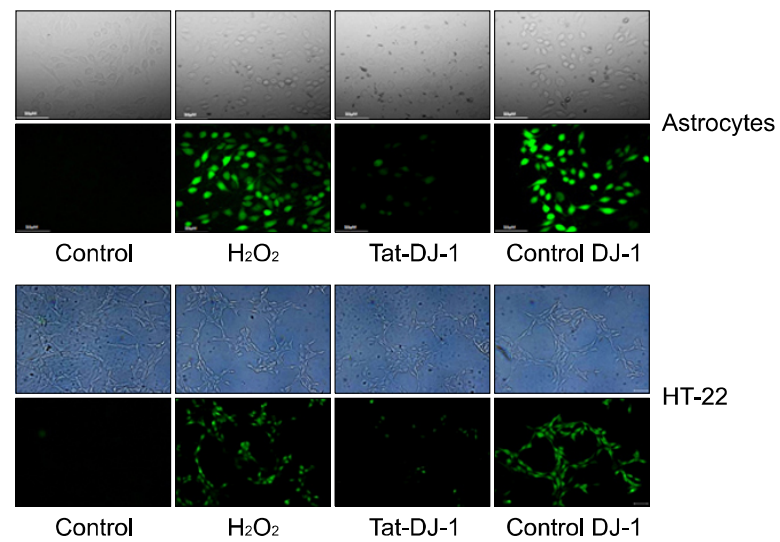

Figure 3. Effects of transduced Tat-DJ-1 on cell viability and ROS generation. Hydrogen peroxide $(0.7 \mathrm{mM})$ was added to astrocytes and HT-22 cells pretreated with Tat-DJ-1 (1-3 $\mu \mathrm{M})$ for $1 \mathrm{~h}$. Cell viabilities were estimated by with a colorimetric assay using MTT (A). ${ }^{*} P<0.05$ and ${ }^{* *} P<0.01$, compared with $\mathrm{H}_{2} \mathrm{O}_{2}$ treated cells. These results are representative of at least three separate experiments. Hydrogen peroxide ( 0.7 $\mathrm{mM}$ ) was added to astrocytes and HT-22 cells pretreated with Tat-DJ-1 (3 $\mu \mathrm{M})$ for $1 \mathrm{~h}$. Intracellular ROS levels were measured after staining with DCFDA (B). Scale bar $=20$ and $50 \mu \mathrm{m}$, respectively.

was measured using an MTT assay after administration of hydrogen peroxide $\left(\mathrm{H}_{2} \mathrm{O}_{2}\right)$. When the astrocytes and $\mathrm{HT}-22$ cells were exposed to $0.7 \mathrm{mM}$ $\mathrm{H}_{2} \mathrm{O}_{2}$, only $45 \%$ and $36 \%$ of cells were viable, respectively. As shown in Figure $3 \mathrm{~A}$, the viability of cells pretreated with Tat-DJ-1 proteins and exposed to $\mathrm{H}_{2} \mathrm{O}_{2}$ increased up to $68 \%$ and $66 \%$. Transduced Tat-DJ-1 protein protects HT-22 cells a similar way to astrocytes. However, control DJ-1 protein did not show a protective effect under the same conditions. These results indicate that transduced Tat-DJ-1 proteins play a defensive role against cell death induced by oxidative stress.

We investigated whether Tat-DJ-1 protein inhibits $\mathrm{H}_{2} \mathrm{O}_{2}$ induced intracellular reactive oxygen species (ROS) generation. To assess the generation of ROS, we used the intracellular oxidation of DCF-DA fluorescent dye. When the astrocytes were exposed to $0.7 \mathrm{mM} \mathrm{H}_{2} \mathrm{O}_{2}$ for 30 min, $\mathrm{H}_{2} \mathrm{O}_{2}$ markedly increased the DCF signal. However, ROS generation by $\mathrm{H}_{2} \mathrm{O}_{2}$ 


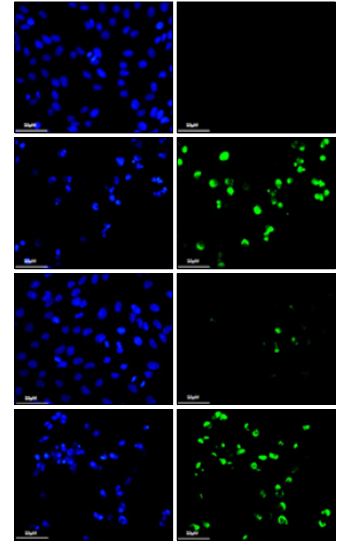

Astrocytes

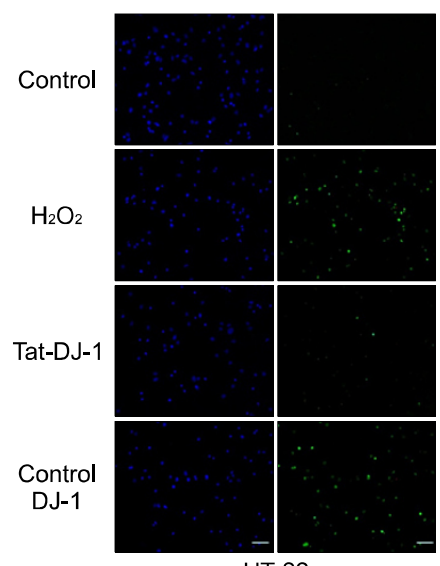

HT-22
Figure 4. Tat-DJ-1 protein protects against $\mathrm{H}_{2} \mathrm{O}_{2}$-induced DNA fragmentation in astrocytes and HT-22 cells. The cells were treated with Tat-DJ-1 $(3 \mu \mathrm{M})$ for $1 \mathrm{~h}$, and then exposed to $\mathrm{H}_{2} \mathrm{O}_{2}(0.7 \mathrm{mM})$ for $18 \mathrm{~h}$. DNA fragmentation was detected by TUNEL staining. These results are representative of at least three separate experiments. Scale bar $=20$ and 50 $\mu \mathrm{m}$, respectively.

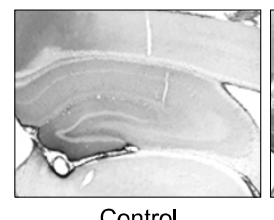

Control

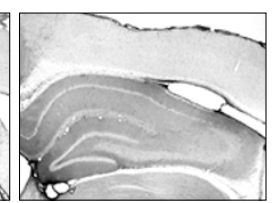

Control DJ-1

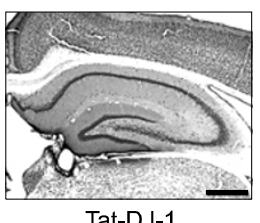

Tat-DJ-1
Figure 5. Transduction of Tat-DJ-1 protein across the blood-brain barrier Transduction of Tat-DJ-1 protein in gerbil brains was analyzed by immunohistochemistry using anti-histidine antibody. Animals were treated with a single injection of Tat-DJ-1 and killed after $8 \mathrm{~h}$.

decreased in the presence of Tat-DJ-1 protein (Figure 3B). ROS generation was quantified using a Fluoroskan ELISA plate reader. Transduced Tat-DJ-1 protein significantly inhibited the ROS production induced by $\mathrm{H}_{2} \mathrm{O}_{2}$ compared to control DJ-1 protein in astrocytes and HT-22 cells.

In order to determine the protective effect of Tat-DJ-1 protein against $\mathrm{H}_{2} \mathrm{O}_{2}$-induced DNA fragmentation, Terminal deoxynucleotidyl transferase (TdT)-mediated biotinylated UTP nick end labeling (TUNEL) staining was performed after treatment with Tat-DJ-1 protein. As shown in Figure $4, \mathrm{H}_{2} \mathrm{O}_{2}$ markedly increased the number of cells stained compared with the control, whereas cells treated with transduced Tat-DJ-1 protein were only slightly stained.

Under the same experimental conditions, we also measured ROS generation and DNA fragmentation in the HT-22 cells. As shown in Figures $3 \mathrm{~B}$ and 4, Transduced Tat-DJ-1 protein efficiently protects the HT-22 cells. These results indicate that Tat-DJ-1 protein efficiently inhibits $\mathrm{H}_{2} \mathrm{O}_{2}$-induced ROS gen-
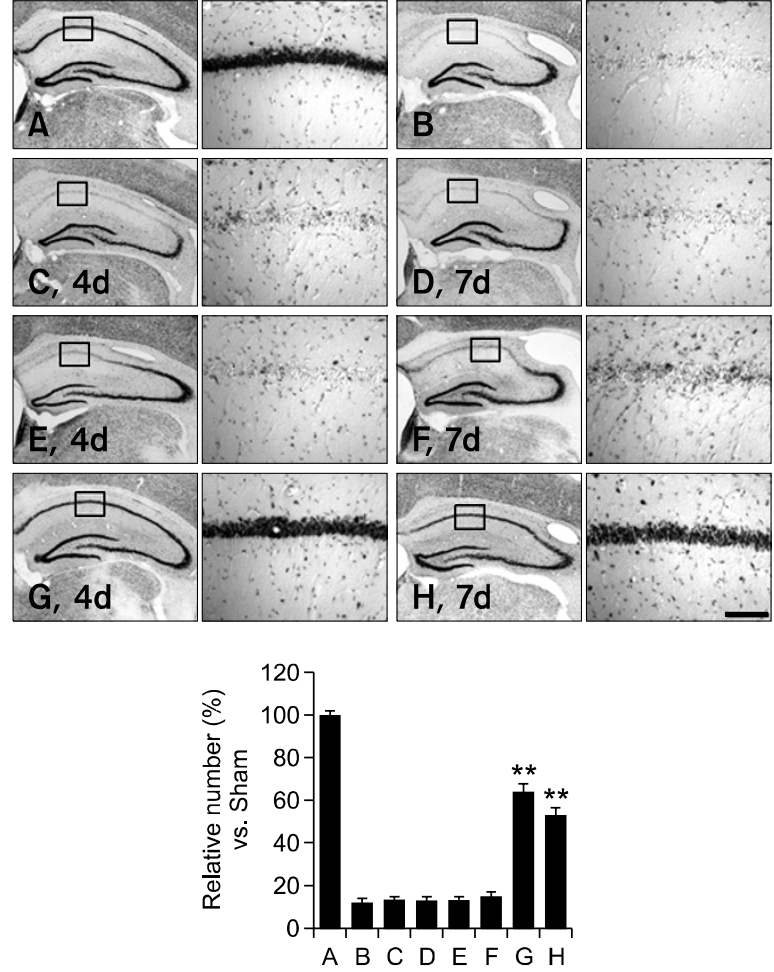

Figure 6. Effect of transduced Tat-DJ-1 on ischemic damage in the CA1 region. Representative photomicrography of the cresyl violet staining in the $C A 1$ region of the hippocampus of the gerbil brain 4 and 7 days after ischemic insults. Negative control ( $A$, normal); positive control ( $B$, vehicle-injected group), control DJ-1 (C, D), Tat peptide (E, F) and Tat-DJ-1 $(3 \mathrm{mg} / \mathrm{kg})$ injected as a single into the gerbil $(\mathrm{G}, \mathrm{H})$. Scale bar $=50 \mu \mathrm{m}$. Relative analysis the cell number of CV-positive neurons in the control and vehicle, respectively. Values are significantly different from the control group, ${ }^{* *} P<0.01$.

eration and DNA fragmentation in neuronal cells.

\section{Transduction of Tat-DJ-1 protein protects against ischemic damage}

We examined whether Tat-DJ-1 protein crossed the blood-brain barrier using immunohistochemistry. As shown in Figure 5, the proteins were not detected in both the Sham-operated and control DJ-1-treated animals. However, DJ-1 protein levels were significantly elevated throughout the brains of Tat-DJ-1-treated animals. These results indicate that Tat-DJ-1 protein efficiently transduced across the blood-brain barrier of the gerbils.

We further examined the effects of transduced Tat-DJ-1 protein on neuronal cell viability after transient forebrain ischemia in a gerbil model. 4 and 7 days following ischemic insult the Tat-DJ-1-treated, control DJ-1-treated, Tat peptide-treated, vehicletreated, and sham-operated control animals were killed for cresyl violet $(\mathrm{CV})$ staining. The protective 


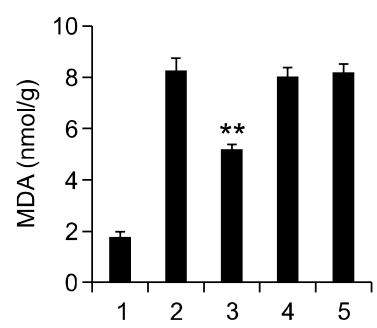

Figure 7. Effect of transduced Tat-DJ-1 on brain malondialdehyde (MDA) levels. Tat-DJ-1 was administrated 30 min before ischemia. At $3 \mathrm{~h}$ after ischemic insult, hippocampi were dissected for measurement of MDA. Lanes are as follows: lane 1, sham-operated group; lane 2, ischemia-induced group; lane 3, Tat-DJ-1-treated group; lane 4, control DJ-1-treated group; lane 5 , Tat peptide-treated group. ${ }^{* *} P<0.01$, compared with ischemia-induced group.

effects of Tat-DJ-1 proteins were evaluated by CV histochemistry (Figure 6). In the vehicle-treated group, the percentage of positive neurons detected was $12 \%$ compared to the sham-operated group. In the Tat-DJ-1 protein treated groups ( 4 and 7 days after ischemic insult), the percentage of positive neurons was $64 \%$ and $53 \%$ respectively compared to the sham-operated group.

We also examined whether Tat-DJ-1 protein inhibits ischemia-induced lipid peroxidation by measuring the levels of malondialdehyde (MDA), a marker of lipid peroxidation, in the hippocampus. As shown in Figure 7, in the vehicle-treated group, MDA levels were markedly increased compared to the sham-operated group. However, in the Tat-DJ-1treated group, MDA levels were significantly decreased compared to the ischemic insult group. In addition, the control DJ-1 and Tat peptide-treated groups showed a similar pattern compared to the ischemic insult group. These results indicate that Tat-DJ-1 protein efficiently transduced across the gerbil blood-brain barrier and effectively protects against neuronal cell damage caused by ischemic insult.

\section{Discussion}

Reactive oxygen species (ROS) are inevitably formed as by-products of various normal cellular processes involving interaction with oxygen. ROS damage macromolecules in cells and play a central role in a variety of pathological processes of human diseases including ischemia (Flyod, 1990; Halliwell and Gutteridge, 1999). DJ-1, known as PARK7, was first identified as an oncogene and is the causative gene of Parkinson's disease (Nagakubo et al., 1997; Bonifati et al., 2003). The association between DJ-1 deficiency and neuronal diseases and increased oxidative stress damage is well known (Menzies et al., 2005; Lucas and Marin, 2007). Although DJ-1 has been considered a potential therapeutic agent against neuronal disease, its inability to enter cells hinders its use for this purpose. Towards that end we investigated the possibility of protein transduction in an effort to deliver DJ-1 protein to cells and tissues. Although the mechanism of transduction is unclear, it is generally accepted that the protein transduction domains (PTDs) pass efficiently across the plasma membrane (Wadia and Dowdy, 2002; Dietz, 2010).

Purified Tat-DJ-1 protein efficiently transduced into astrocyte cells in a time- and dose-dependent manner. Protein transduction efficiency depends on a several factors such as the target proteins, the cell types, and PTDs. The different transduction efficiencies may be due to differences in degrees of unfolding, polarity, or protein conformation.

ROS have the potential to damage cellular macromolecules including proteins, lipids, and nucleic acids. Thus, we examined the viability of cells with transduced DJ-1 proteins after the administration of hydrogen peroxide $\left(\mathrm{H}_{2} \mathrm{O}_{2}\right)$. When the astrocytes were exposed to $0.7 \mathrm{mM} \mathrm{H}_{2} \mathrm{O}_{2}$, only $45 \%$ of cells were viable. The viability of cells pretreated with Tat-DJ-1 proteins exposed to $\mathrm{H}_{2} \mathrm{O}_{2}$ increased up to $68 \%$. The same patterns were obtained with HT-22 cells. These results indicate that transduced Tat-DJ-1 protein plays a defensive role against cell death induced by oxidative stress in the cells. Yanagida et al. (2009) demonstrated that recombinant GST-DJ-1 protein directly trapped hydroxyl radicals and inhibited $\mathrm{H}_{2} \mathrm{O}_{2}$-induced neuronal cell death. In addition, they suggest that DJ-1 protein may be useful for novel therapeutic agents against various oxidative stress-mediated disorders.

We further observed that Tat-DJ-1 protein protects against ischemic insults by lipid peroxidation and immunohistochemistry in an animal model. Several studies have shown that the release of ROS and increases in lipid peroxidation can be detected early after ischemic insult (Chan, 2001; Wang et al., 2005). The levels of brain MDA, a marker of lipid peroxidation, were markedly increased after ischemic insults whereas the increased MDA levels were significantly decreased by transduced Tat-DJ-1 protein. However, control DJ-1 protein did not show the protective effects. We also confirmed the protective effects of the Tat-DJ-1 proteins by immunohistochemistry at 4 and 7 days after ischemia. The magnitude of the protective effect of Tat-DJ-1 protein was observed in the $64 \%$ and $53 \%$ survival rates of CA1 neurons. However, control DJ-1 protein did not show protective effects compared to the sham-operated group. These results concur with Yanagisawa et al. (2008) and 
Yanagida et al. (2009) which conclude that DJ-1 protein exhibits a neuroprotective effect by reducing ROS-mediated neuronal injury (Yanagisawa et al., 2008; Yanagida et al., 2009). Also, our results indicate that Tat-DJ-1 protein is associated with delayed neuronal death in the CA1 region after ischemia and attenuates neuronal damage after ischemic insult.

In summary, we demonstrated that Tat-DJ-1 protein can be efficiently transduced in vitro and in vivo and markedly protects against oxidative stress-induced cell death and ischemic insults. Although the detailed mechanism remains to be explored, Tat-DJ-1 protein may provide a new strategy for protecting against cell destruction resulting from ischemic damage and further may provide an opportunity for the therapeutic treatment of various human diseases.

\section{Methods}

\section{Materials}

Astrocyte cells, rat astrocytoma cell line C6, were obtained with from the Korean Cell Line Research Foundation, Seoul, Korea. The mouse hippocampal cell lines, HT-22 cells, were kindly provided by Dr. Sang Hyun Sung (Seoul National University). Plasmid pET-15b and Escherichia coli strain BL21 (DE3) were obtained from Novagen. The FBS and antibiotics were purchased from Gibco BRL. Oligonucleotides were synthesized from Gibco BRL custom primers. $\mathrm{Ni}^{2+}$-nitrilotriacetic acid Sepharose superflow was purchased from Qiagen. Synthetic Tat peptides were purchased from PEPTRON (Daejeon, Korea). All other chemicals and reagents were of the highest commercial grade available.

\section{Expression and purification of Tat-DJ-1 proteins}

A cell-permeable HIV-1 Tat expression vector was prepared in our laboratory as described previously (Kwon et al., 2000). The cDNA sequence for human DJ-1 was amplified by PCR using the sense primer 5'-CTCGAGGCTTC CAAAAGAGC-3' and the antisense primer, 5'-GGATCCCT AGTCTTTAAGAA-3'. The resulting PCR product was subcloned in a TA cloning vector and ligated into the pTat expression vector, with six histidine open-reading frames to generate the expression vector, and cloned into $E$. coli $\mathrm{DH} 5 \alpha$ cells.

The recombinant Tat-DJ-1 plasmid was transformed into E. coli BL21 cells and induced with $0.5 \mathrm{mM} \mathrm{IPTG}$ at $37^{\circ} \mathrm{C}$ for 3-4 h. Harvested cells were lysed by sonication and the recombinant Tat-DJ-1 was purified using a $\mathrm{Ni}^{2+}$-nitrilotriacetic acid Sepharose affinity column and PD-10 column chromatography. The protein concentration was estimated by the Bradford procedure using bovine serum albumin as a standard (Bradford, 1976).

\section{Cell culture and transduction of Tat-DJ-1 protein}

Astrocytes and mouse hippocampal HT-22 cells were cultured in Dulbecco's minimum essential medium (DMEM; Lonza BioWhittaker, MD) supplemented with $10 \%$ FBS and antibiotics $(100 \mu \mathrm{g} / \mathrm{ml}$ streptomycin, $100 \mathrm{U} / \mathrm{ml}$ penicillin) at $37^{\circ} \mathrm{C}$ under humidified conditions of $95 \%$ air and $5 \% \mathrm{CO}_{2}$.

For the transduction of Tat-DJ-1 protein, the cells were treated with various concentrations of Tat-DJ-1 protein for $1 \mathrm{~h}$. The cells were treated with trypsin-EDTA and washed with phosphate-buffered saline (PBS) and harvested for the preparation of cell extracts to perform Western blot analysis.

\section{Western blot analysis}

The proteins in cell lysates were resolved by $12 \%$ sodium dodecyl sulfate-polyacrylamide gel electrophoresis (SDSPAGE). The resolved proteins were electrotransferred to a nitrocellulose membrane, which was then blocked with 5\% non-fat dry milk in PBS. The membrane was probed with a rabbit antihistidine polyclonal antibody (1:1000; Santa Cruz Biotechnology, Santa Cruz, CA), followed by incubation with goat antirabbit immunoglobulins (dilution 1:10,000; Sigma-Aldrich, St. Louis, MO). The bound antibodies were then visulalized by enhanced chemiluminescence according to the manufacturer's instructions (Amersham, Franklin Lakes, NJ).

\section{Fluorescence microscopy analysis}

Astrocytes and HT-22 cells were grown on coverslips treated with $3 \mu \mathrm{M}$ of Tat-DJ-1 proteins. Following incubation for $1 \mathrm{~h}$ at $37^{\circ} \mathrm{C}$, the cells were washed twice with PBS and fixed with $4 \%$ paraformaldehyde for $5 \mathrm{~min}$ at room temperature. The cells were permeabilized and blocked for 30 min with $3 \%$ bovine serum albumin, $0.1 \%$ Triton X-100 in PBS (PBS-BT) and washed with PBS-BT. The primary antibody (His-probe, Santa Cruz Biotechnology) was diluted 1:2000, and incubated for $90 \mathrm{~min}$ at room temperature. The secondary antibody (Alexa fluor 488, Invitrogen) was diluted 1:15000, and incubated for $45 \mathrm{~min}$ at room temperature in the dark. Nuclei were stained for 5 min with $1 \mu \mathrm{g} / \mathrm{ml}$ DAPI (Roche). The distribution of fluorescence was analyzed by fluorescence microscopy (Nikon eclipse 80i, Japan).

\section{3-(4,5-dimethylthiazol-2-yl)-2,5-dipheyltetrazolium bromide (MTT) assay}

A MTT assay was used to determine the viability of astrocyte cells treated with hydrogen peroxide $\left(\mathrm{H}_{2} \mathrm{O}_{2}\right)$. The cells were pretreated with Tat-DJ-1 protein $(1-3 \mu \mathrm{M})$ for $1 \mathrm{~h}$, after which $\mathrm{H}_{2} \mathrm{O}_{2}(0.7 \mathrm{mM})$ was added to the culture medium for $24 \mathrm{~h}$. The absorbance was measured at $540 \mathrm{~nm}$ using an ELISA microplate reader (Labsystems Multiskan $\mathrm{MCC} / 340$ ) and the cell viability was defined as the $\%$ of untreated control cells.

\section{Measurement of reactive oxygen species (ROS)}

ROS levels were determined using the ROS sensitive dye 
2',7'-dichlorofluorescein diacetate (DCF-DA), which is converted by ROS into the highly fluorescent 2 ', $7^{\prime}$-dichlorofluorescein (DCF). Astrocytes and HT-22 cells were incubated in the absence or presence of Tat-DJ-1 $(3 \mu \mathrm{M})$ for $1 \mathrm{~h}$, and then treated with $\mathrm{H}_{2} \mathrm{O}_{2}(0.7 \mathrm{mM})$ for 30 min. Cells were treated with DCF-DA $(15 \mu \mathrm{M})$ for $15 \mathrm{~min}$ and then washed twice with PBS. The level of DCF fluorescence, reflecting the concentration of ROS, was measured by fluorescent microscopy using a fluoroskan enzyme-linked immunosorbent assay (ELISA) plate reader calibrated for excitation at $485 \mathrm{~nm}$ and emission at $538 \mathrm{~nm}$ (Labsystems Oy, Helsinki, Finland).

\section{TUNEL assay}

Astrocytes and HT-22 cells were incubated in the absence or presence of Tat-DJ-1 $(3 \mu \mathrm{M})$ for $1 \mathrm{~h}$, and then treated with $\mathrm{H}_{2} \mathrm{O}_{2}(0.7 \mathrm{mM})$ for $18 \mathrm{~h}$. Terminal deoxynucleotidyl transferase (TdT)-mediated biotinylated UTP nick end labeling (TUNEL) staining was performed using the Cell Death Detection kit (Roche Applied Science) according to the manufacturer's instructions. Images were taken using a fluorescence microscope (Nikon eclipse 80i, Japan).

\section{Experimental animals and induction of cerebral forebrain ischemia}

Mongolian gerbils (Meriones unguiculatus; 65-75 g) were obtained from the Experiment Animal Center, at Hallym University. The animals were housed in a conventional state at an adequate temperature $\left(23^{\circ} \mathrm{C}\right)$ and humidity $(60 \%)$ controlled with a 12-h light/12-h dark cycle, and freely access to food and water.

All experimental procedures involving animals and their care conformed to the Guide for the Care and Use of Laboratory Animals of the National Veterinary Research \& Quarantine Service of Korea and were approved by the Hallym Medical Center Institutional Animal Care and Use Committee.

The cerebral forebrain ischemia models were performed according to a method previously described (An et al., 2008; Kim et al., 2010). To determine whether transduced Tat-DJ-1 protects against ischemic damage, gerbils were i. p. injected with Tat-DJ-1 proteins ( $3 \mathrm{mg} / \mathrm{kg}) 30 \mathrm{~min}$ before the occlusion of common carotid arteries. The common carotid arteries were isolated, freed of nerve fibers, and occluded with non-traumatic aneurysm clips. Complete interruption of blood flow was confirmed by observing the central artery in the eyeball using an ophthalmoscope. After 5 min of occlusion, the aneurysm clips were removed. The restoration of blood flow (reperfusion) was observed directly via ophthalmoscope.

Brain tissue samples were obtained at 4 and 7 days after ischemia-reperfusion, perfused transcardially with PBS ( $\mathrm{pH} 7.4$ ), followed by $4 \%$ paraformaldehyde in $0.1 \mathrm{M}$ PBS $(\mathrm{pH} 7.4)$ in the sham-operated group, vehicle-treated, Tat peptide-treated, control DJ-1- and Tat-DJ-1-treated groups (each $3 \mathrm{mg} / \mathrm{kg}$ ). The brain tissues were cryoprotected by infiltration with $30 \%$ sucrose overnight. The tissues were then frozen and sectioned with a cryostat at $50 \mu \mathrm{m}$ and consecutive sections were collected in six-well plates containing PBS. Cresyl violet staining was performed as pre- viously described (An et al., 2008; Kim et al., 2010).

\section{Quantitative analysis}

The neuronal number and intensity of immunoreactivity were calculated using an image analyzing system. The staining intensity of the immunoreactive structures was evaluated as the relative optical density (ROD): the relative $\%$ of the control level is shown in the graph. The data were analyzed using one-way ANOVA to determine statistical significance.

\section{Acknowledgements}

This work was supported by a research grant from the Brain Research Center of the $21^{\text {st }}$ Century Frontier Research Program (2010K000808) and in part by a Priority Research Centers Program grant (2012-0006695) through the National Research Foundation funded by the Ministry of Education, Science and Technology, Korea.

\section{References}

Alexandrova M, Bochev P, Markova V, Bechev B, Popova M, Danovska M, Simeonova V. Dynamics of free radical processes in acute ischemic stroke: influence on neurological status and outcome. J Clin Neurosci 2004;11:501-6

Aleyasin H, Rousseaux MWC, Phillips M, Kim RH, Bland RJ, Callaghan S, Slack RS, During MJ, Mak TW, Park DS. The Parkinson's disease gene DJ-1 is also a key regulator of stroke-induced damage. Proc Natl Acad Sci USA 2007;104: 18748-53

An JJ, Lee YP, Kim SY, Lee SH, Lee MJ, Jeong MS, Kim DW, Jang SH, Yoo KY, Won MH, Kang TC, Kwon OS, Cho SW, Lee KS, Park J, Eum WS, Choi SY. Transduced human PEP-1-heat shock protein 27 efficiently protects against brain ischemic insult. FEBS J 2008;275:1296-308

Andersen JK. Oxidative stress in neurodegeneration: cause or consequence? Nat Med 2004;10:S18-25

Bonifati V, Rizzu P, van Baren MJ, Schaap O, Breedveld GJ, Krieger E, Dekker MC, Squitieri F, Ibanez P, Joose M, van Duijn CM, Oostra BA, Heutink P. Mutations in the DJ-1 gene associated with autosomal recessive early-onset parkinsonism. Science 2003;299:256-9

Bradford MM. A rapid and sensitive method for the quantitation of microgram quantities utilizing the principle of protein-dye binding. Anal Biochem 1976;72:248-54

Chan $\mathrm{PH}$. Reactive oxygen radicals in signaling and damage in the ischemic brain. J Cereb Blood Flow Metab 2001;21: 2-14

Choi HS, An JJ, Kim SY, Lee SH, Kim DW, Yoo KY, Won MH, Kang TC, Kwon HJ, Kang JH, Cho SW, Kwon OS, Park J, Eum WS, Choi SY. PEP-1-SOD fusion protein efficiently protects against paraquat-induced dopaminergic neuron damage in a Parkinson disease mouse model. Free Radic Biol Med 2006;41:1058-68 
Dietz GP. Cell-penetrating peptide technology to deliver chaperones and associated factors in diseases and basic research. Curr Pharm Biotechnol 2010;11:167-74

Eum WS, Kim DW, Hwang IK, Yoo KY, Kang TC, Jang SH, Choi HS, Choi SH, Kim YH, Kim SY, Kwon HY, Kang JH, Kwon OS, Cho SW, Lee KS, Park J, Won MH, Choi SY. In vivo protein transduction: Biologically active intact PEP-1-superoxide dismutase fusion protein efficiently protects against ischemic insult. Free Radic Biol Med 2004;37:1656-69

Floyd RA. Role of oxygen free radicals in carcinogenesis and brain ischemia. FASEB J 1990;4:2587-97

Gupta A, Dawson VL, Dawson TM. What causes cell death in Parkinson's disease? Ann Neurol 2008;64:S3-15

Halliwell B, Gutteridge JMC. Free radicals in biology and medicine. 1999. Oxford University Press, Oxford.

Hata R, Maeda K, Hermann D, Mies G, Hossmann KA. Evolution of brain infarction after transient focal cerebral ischemia in mice. J Cereb Blood Flow Metab 2000;20:937-46

Kim DW, Lee SH, Jeong MS, Sohn EJ, Kim MJ, Jeong HJ, An JJ, Jang SH, Won MH, Hwang IK, Cho SW, Kang TC, Lee KS, Park J, Yoo KY, Eum WS, Choi SY. Transduced Tat-SAG fusion protein protects against oxidative stress and brain ischemic insult. Free Radic Biol Med 2010;48:969-77

Kwon HY, Eum WS, Jang HW, Kang JH, Ryu JY, Lee BR, Jin LH, Park J, Choi SY. Transduction of Cu, Zn-superoxide dismutase mediated by an HIV-1 Tat protein basic domain into mammalian cells. FEBS Lett 2000;485:163-7

Lee SJ, Kim SJ, Kim IK, Ko J, Jeong CS, Kim GH, Park C, Kang SO, Suh PG, Lee HS, Cha SS. Crystal structures of human DJ-1 and Escherichia coli Hsp31, which share an evolutionarily conserved domain. J Biol Chem 2003;278: 44552-9

Lucas JI, Marin I. A new evolutionary paradigm for the Parkinson disease gene DJ-1. Mol Biol Evol 2007;24:551-61

Margaill I, Plotkine M, Lerouet D. Antioxidant strategies in the treatment of stroke. Free Radic Biol Med 2005;39:429-43

Menzies FM, Yenisetti SC, Min KT. Roles of Drosophila DJ-1 in survival of dopaminergic neurons and oxidative stress. Curr Biol 2005;15:1578-82

Nagakubo D, Taira T, Kitaura H, Ikeda M, Tamai K, Iguchi-Ariga
SMM, Ariga H. DJ-1, a novel oncogene which transforms mouse NIH3T3 cells in cooperation with rats. Biochem Biophys Res Commum 1997;231:509-13

Schaller B, Graf R. Cerebral ischemia and reperfusion: the pathophysiologic concept as a basis for clinical therapy. J Cereb Blood Flow Metab 2004;24:351-71

Wadia JS, Dowdy SF. Protein transduction technology. Curr Opin Biotechnol 2002;13:52-6

Wadia JS, Dowdy SF. Modulation of cellular function by TAT mediated transduction of full length protein. Curr Protein Pept Sci 2003;4:97-104

Wang $Q$, Sun AY, Simonyi A, Jensen MD, Shelat PB, Rottinghaus GE, MacDonald RS, Miller DK, Lubahn DE, Weisman GA, Sun GY. Neuroprotective mechanisms of curcumin against cerebral ischemia-induced neuronal apoptosis and behavioral deficits. J Neurosci Res 2005;82: 138-48

Wilson MA, St Amour CV, Collins JL, Ringe D, Petsko GA. The 1.8-A resolution crystal structure of YDR533Cp from Saccharomyces cerevisiae: a number of the DJ-1/ThiJ/Pfpl superfamily. Proc Natl Acad Sci USA 2004;101:1531-6

Xu J, Zhong N, Wang H, Elias JE, Kim CY, Woldman I, Pifl C, Gygi SP, Geula C, Yankner BA. The Parkinson's disease associated with $\mathrm{DJ}-1$ protein is a transcriptional co-activator that protects against neuronal apoptosis. Hum Mol Genet 2005; 14:1231-41

Yanagida T, Tsushima J, Kitamura Y, Yanagisawa D, Takata K, Shibaike T, Yamamoto A, Taniguchi T, Yasui H, Taira T, Morikawa S, Inubushi T, Tooyama I, Ariga H. Oxidative stress induction of DJ-1 protein in reactive astrocytes scavenges free radicals and reduces cell injury. Oxid Med Cell Longev 2009;2:36-42

Yanagisawa D, Kitamura Y, Inden M, Takata K, Taniguchi T, Morikawa S, Morita M, Inubushi T, Tooyama I, Taira T, Iguchi-Ariga SMM, Akaike A, Ariga H. DJ-1 protects against neurodegeneration caused by focal cerebral ischemia and reperfusion in rats. J Cereb Blood Flow Metab 2008;28: 563-78

Zhou W, Zhu M, Wilson MA, Petsko GA, Fink AL. The oxidation state of DJ-1 regulates its chaperone activity toward alpha-snyuclein. J Mol Biol 2006;356:1036-48 


\section{Retraction: Protective effects of transduced Tat-DJ-1 protein against oxidative stress and ischemic brain injury}

Hoon Jae Jeong, Dae Won Kim, Mi Jin Kim, Su Jung Woo, Hye Ri Kim, So Mi Kim, Hyo Sang Jo, Hyun Sook Hwang, Duk-Soo Kim, Sung-Woo Cho, Moo Ho Won, Kyu Hyung Han, Jinseu Park, Won Sik Eum and Soo Young Choi

Experimental \& Molecular Medicine (2013) 45, e24; doi:10.1038/emm.2013.54; published online 24 May 2013

Retraction to: Experimental \& Molecular Medicine (2012) 44, 586-593; doi:10.3858/emm.2012.44.10.067

The following article from Experimental \& Molecular Medicine has been retracted by agreement between the authors, the journal's Editor-in-Chief and the Korean Society for
Biochemistry and Molecular Biology. The article has been retracted because of concerns about the data represented in Figure 1. When the concerns were presented to the authors, they agreed that they resulted in the integrity of the paper being uncertain and so requested the retraction be enacted. 